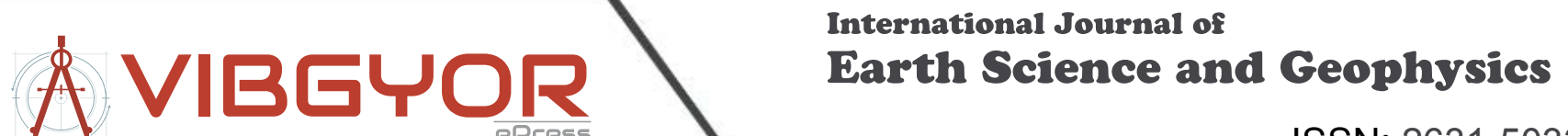

\section{Seismicity and Tectonics of the Black Sea}

\section{Dogan Kalafat ${ }^{1,2 *}$}

${ }^{1}$ Boğaziçi University Kandilli Observatory and ERI, Turkey

${ }^{2}$ MIT Department of Earth, Atmospheric \& Planetary Sciences ERL, USA

\begin{abstract}
The Black Sea, a complex basin between the Arabian, Anatolian and Eurasian plates, is a feature of special interest for understanding the geologic history of the region. It was formed as a "back-arc" basin over the subduction zone during the closing of the Tethys Ocean. In this paper, we present the seismic activites and fault mechanisms of earthquakes in and around the margins of the Black Sea. An increase of broad-band seismic stations since 2005 around the Black Sea, especially in Turkey, has provided the capability for the detection, location and source mechanism studies of earthquakes in the Black Sea basins. The data show that there are a significant number of earthquakes in the Black Sea, mostly of magnitude $M_{w}=4.0$ or smaller. The seismicity increases toward the margins, with the largest events at the margins. The focal mechanisms indicate primarily N-S compression with some E-W component. The mechanisms are consistent with the GPS observations, where Westward motion of the Anatolian Plate and N-S deformation of the Caucasus take up most of the motion of the Arabian Plate. Only small motions (about $1 \mathrm{~mm}$ per year) are transmitted through the Pontides, and the Black Sea is being compressed in N-S direction. In this study we locate and determine fault plane solutions of 25 recent earthquakes, with a magnitude higher than $M=3.7$, in the region and combined these with existing network data from the margins, in order to determine the current tectonics.
\end{abstract}

\section{Keywords}

Black sea, Oceanic basins, Seismicity, Focal mechanisms, Stress analysis

\section{Introduction}

In the past few decades, the Black Sea has been the subject of intense geological and geophysical studies, including deep seismic sounding, reflection profiling, gravity and magnetic surveys for scientific and petroleum exploration purposes $[1,2]$.

The region is controlled bythe collision of the Arabian and Eurasian plates of mid-Miocen age. This type of thrust generation as a result of compressional regime extends east-west.

Avagyan, et al. [3] deal with the recent tectonic stress evolution in the area, especially the Lesser Caucasus and adjacent regions. The present stress field, derived from the kinematics of active faults, corresponds to a strike- slip regime with both transtensional and transpressional characteristics. However, both the micro fault kinematic data and the distribution of Neogene to Quaternary volcanic clusters demonstrate changes of the stress field orientation through time since the beginning of the Arabia-Eurasian collision. A NW-SE orientation of compression was dominant between the Palaeogene and the late Early Miocene, a NE-SW orientation prevailed between the Late Miocene and the Quaternary.

According to previous GPS studies, the shortening rate axes are almost perfectly oriented at $45^{\circ}$ to the fault plane for right lateral slip on the North Anatolian Fault (NAF). Shortening axes are normal to the thrust structures in the Caucasus [4-6] as shown in Figure 1.

*Corresponding author: Doğan Kalafat, Boğaziçi University Kandilli Observatory and ERI, 34684 ÇengelköyIstanbul, Turkey, MIT Department of Earth, Atmospheric \& Planetary Sciences ERL, 77 Mass. Ave. 54-612 Cambridge, 02139 MA-USA, E-mail: kalafato@boun.edu.tr

Received: April 01, 2016: Accepted: June 23, 2017: Published: June 26, 2017

Copyright: (C) 2017 Kalafat D. This is an open-access article distributed under the terms of the Creative Commons Attribution License, which permits unrestricted use, distribution, and reproduction in any medium, provided the original author and source are credited. 


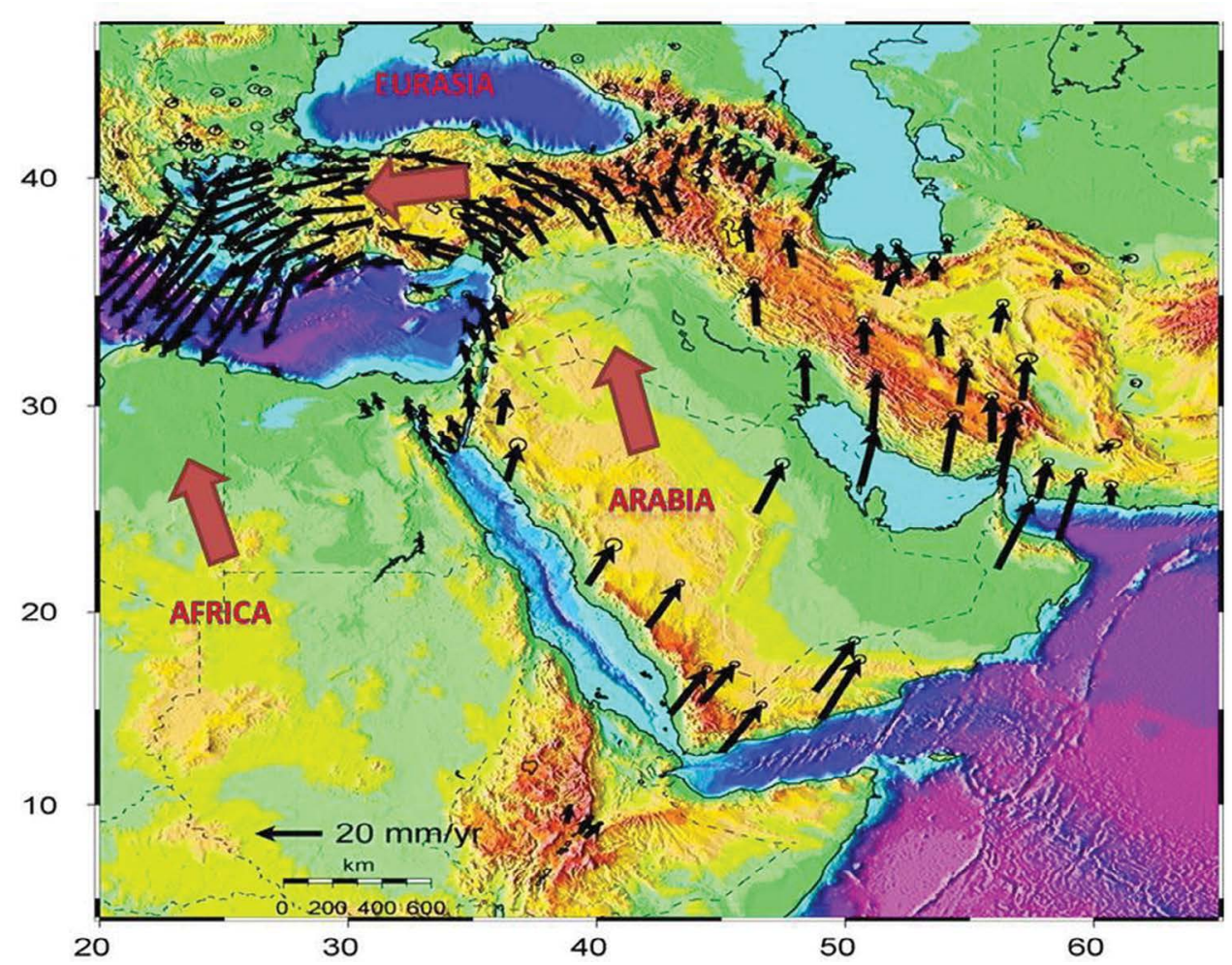

Figure 1: Main tectonic structures, GPS Velocity distribution and movement directions [6].

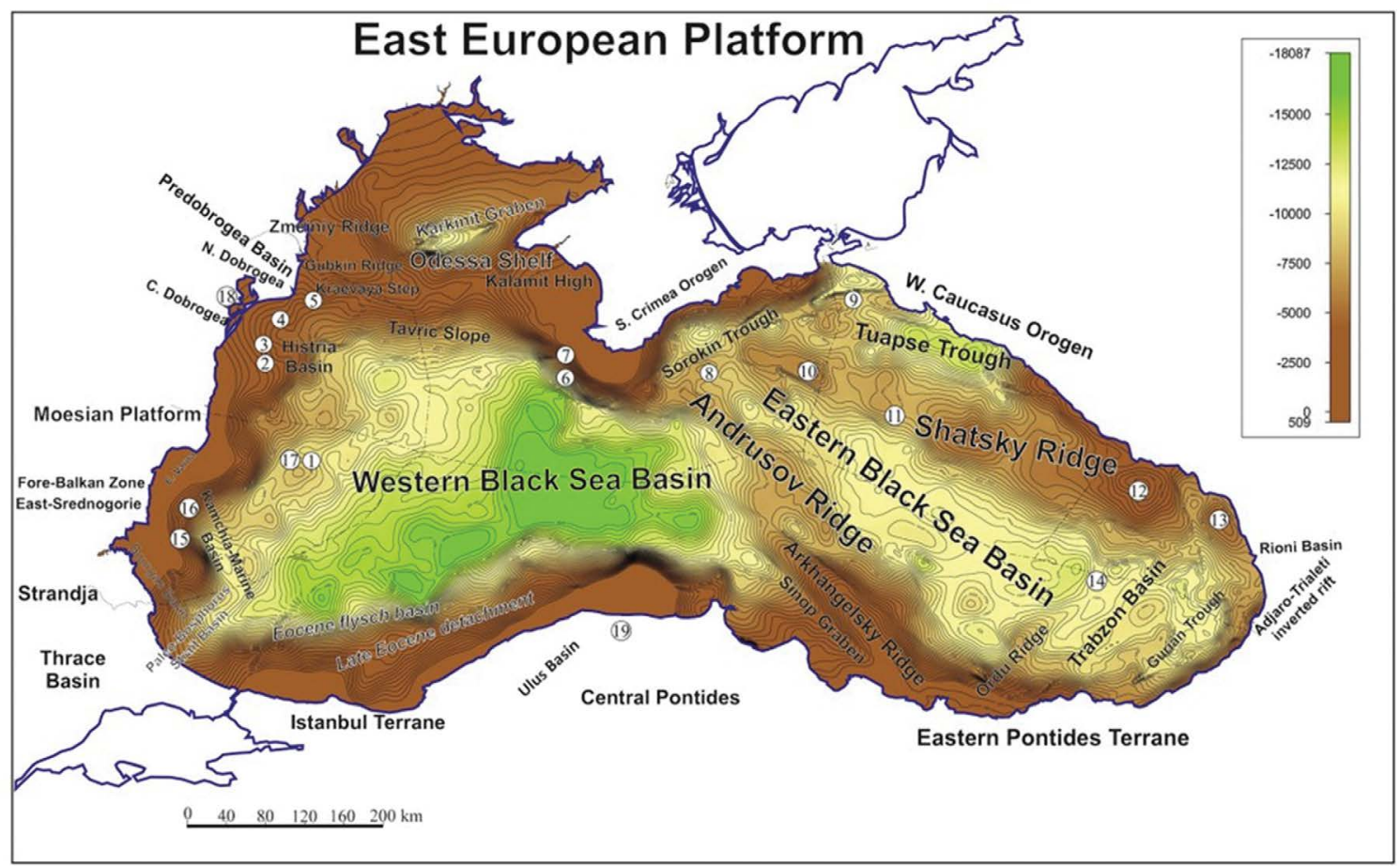

Figure 2: Basement topography of the Black Sea Basin, and the prominent features [7].

The Black Sea, consists of the two oceanic basins separated bymid sea ridges (Figure 2). There are obvious implications for the geometry of extension and rifting within the western and eastern Black Sea basins and the role of broader plate configuration and kinematics in controlling controlling the structures [1].
The deepest part of the basins have oceanic crustbelow a thick cover of sediments, at a depth of about $10 \mathrm{~km}$. The margins and the ridges have continental crusts $[1,7,8,10]$.

According to the previous studies in the region using multi-channel deep seismic reflection-refraction, gravity and magnetic data, the eastern and western basins with 


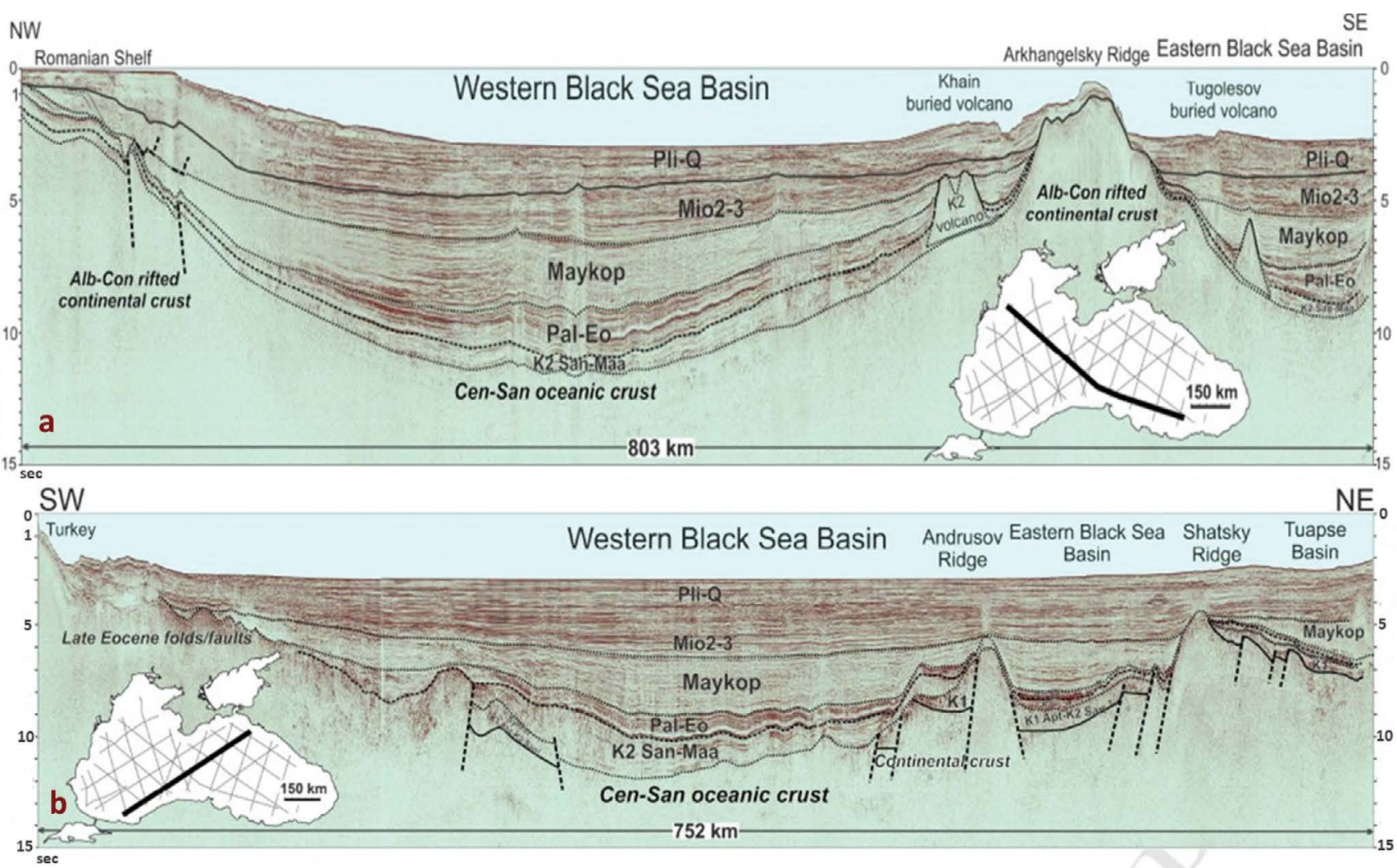

Figure 3: Seismic section along two seismic lines in the NW(a) and NE(b) directions. The sections show the sedimentary layers and basement topography [10].

oceanic crust, show the different structural features [913] (Figure 3).

Geological and geophysical evidence including offshore seismic reflection profiles [14], offshore morphology [15], onshore geology and morphology [16], and recent seismic activity $[17,18]$ support the idea that the compressional tectonic regime is still active in the Eastern Black Sea region. South-west part of the Black Sea do not show important seismic activity to decide whether compressional or tensional regime is active.

Black Sea comprises western and eastern sub-basins which mainly opened in the Eocene [19]. The northern margin of the Black Sea has been identified as active thrusting along the Greater Caucuses from Georgia to the Crimea [20,21].

It is seperated by the mid-Black Sea ridge, a region of thinned continent crust, from the north-west-trending east Black Sea basin, which has oceanic crust with $<12$ $\mathrm{km}$ of sediment cover. Unlike the west Black Sea basin, the ridges and basins in the eastern Black Sea are intersected by a large number of faults [14].

In this paper, we present the seismicity and fault mechanisms of earthquakes in and around the margins of the Black Sea.

\section{Seismicity}

Previously, the former Soviet Union, Bulgaria, Ro- mania, Turkey have publised various earthquake catalogs about seismicity. But because of the lack of sufficient seismic stations in the region, catalogs were not homogeneous and complete. Therefore, the detection of the earthquakes was not complete.

Although seismic activity is sparse in the basins relative to the surrounding region of the Caucasus and Turkey, the broad-band seismic networks established in surrounding countries, especially in Turkey since 2005, have provided the capability for the detection, location and source mechanism studies of earthquakes in the Black Sea basins (Figure 4) [22].

In the previous studies, seismicity in the Black Sea has been considered in general terms. A preliminary study about fault plane solutions for recent earthquakes was published by Bayrak, et al. [23]. In this study, all the available data in the catalogue are used [24]. Figure 5 shows the cumulative number of earthquakes since 1976. Changes of slope in the curve in Figure 5 are due to the increased number of stations and detection capabilities.

Significant increase in the number of earthquakes was seen in the region especially after 2006, primarily due to the new stations established in this region after 2005. Frequency-Magnitude distributions of earthquakes are shown in Figure 6 for two different time intervals: 19001976 and 1976-2015. The recent period shows the great improvement in detection, with the magnitude of com- 


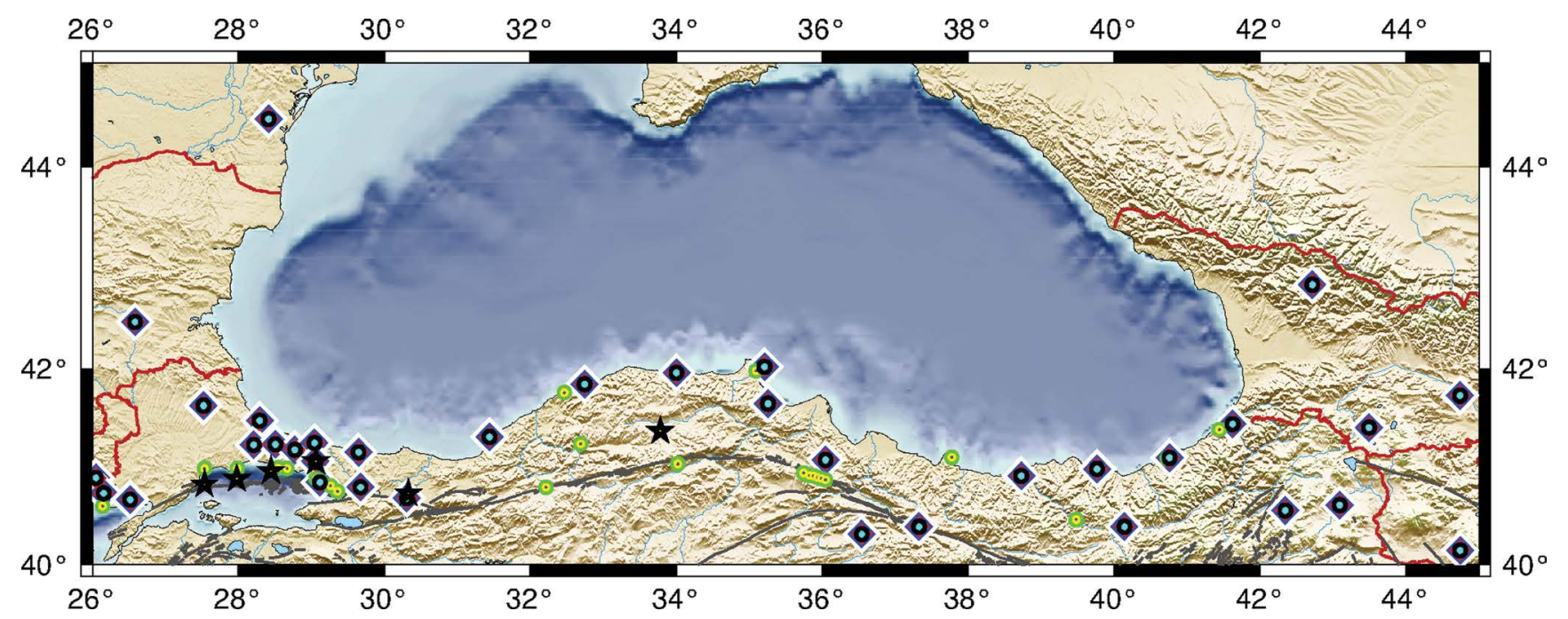

Figure 4: Seismic stations in the region (diamonds show broad-band BB, Green circles the strong-motion SM), Stars show short period SP-with strong motion SM or BB stations).

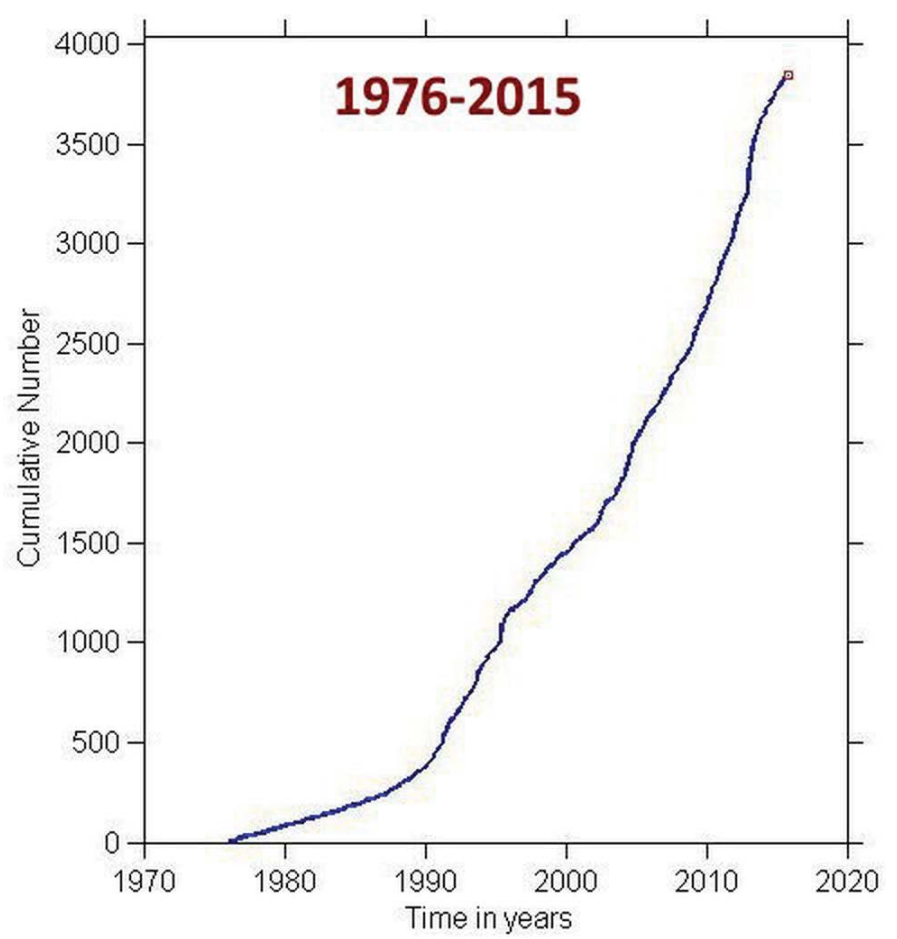

Figure 5: Number of earthquake occurrence - time correlation (distribution of the earthquakes by years between 1976 to 2015).

pleteness $M_{L}=2.7$ in the Black Sea region. For our study we used earthquakes $M \geq 3.0$.

Frequency-Magnitude distribution was analyzed by two different methods. Maximum Likelihood (MLM) [25,26] and Entire Magnitude Range (EMR) [27], and are shown in Figure 6. The results were similar.

There are a significant number of earthquakes in the Black Sea, mostly of magnitude $\mathrm{M}_{\mathrm{w}}=4.0$ or smaller (Figure 7).

The seismicity increases toward the margins, with the largest events at the margins. The seismic activity in the region is greater offshore of Georgia, along the basin edges between Crimea and Russia, Bulgaria-Romania, the Bulgaria-Turkey-Trachea borderline and the middle part of Southern Black Sea - offshore Turkey. The Western and Eastern basin of the Black Sea - inner basin have very few earthquakes. The seismicity pattern in the northeastern Turkey and the Caucasus corresponds to the plate interactions.

\section{Source Mechanism}

Using the data from broad-band stations, we calculated CMT for earthquakes with magnitudes higher than $\mathrm{M}=3.7$, which occured between 2006 and 2015 (Figure 8 and Table 1) [28-30]. We used regionally recorded 


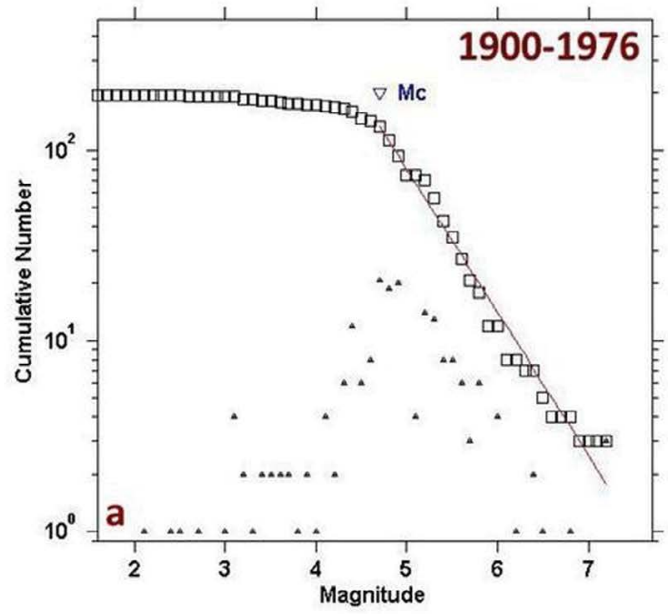

Maximum Likelihood Solution

b-value $=0.751+1-0.06$, a value $=5.66$, a value $($ annual $)=3.77$ Magnitude of Completeness $=4.7$

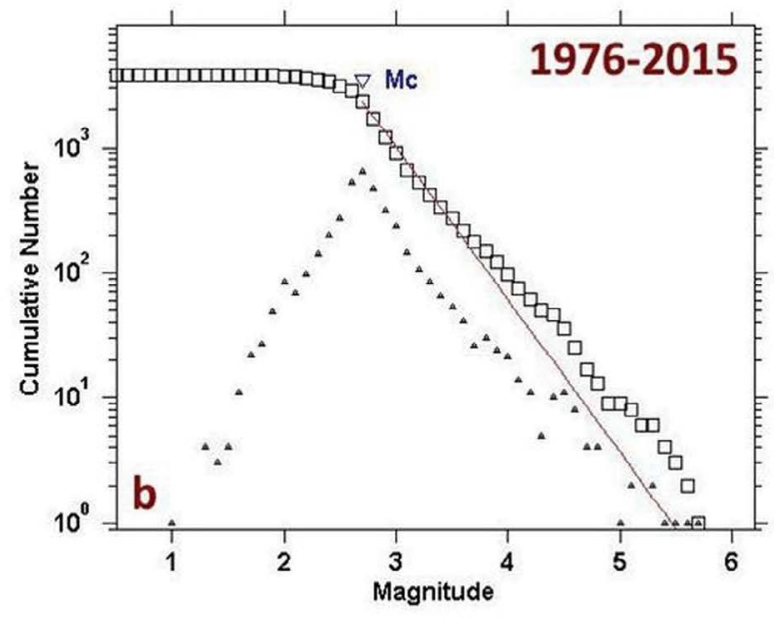

Maximum Likelihood Solution

b-value $=1.22+\{-0.03$, a value $=6.66$, a value $($ annual $)=5.06$

Magnitude of Completeness $=2.7$

Figure 6: Frequency-Magnitude relation for two different time periods and detection threshold (Mc).

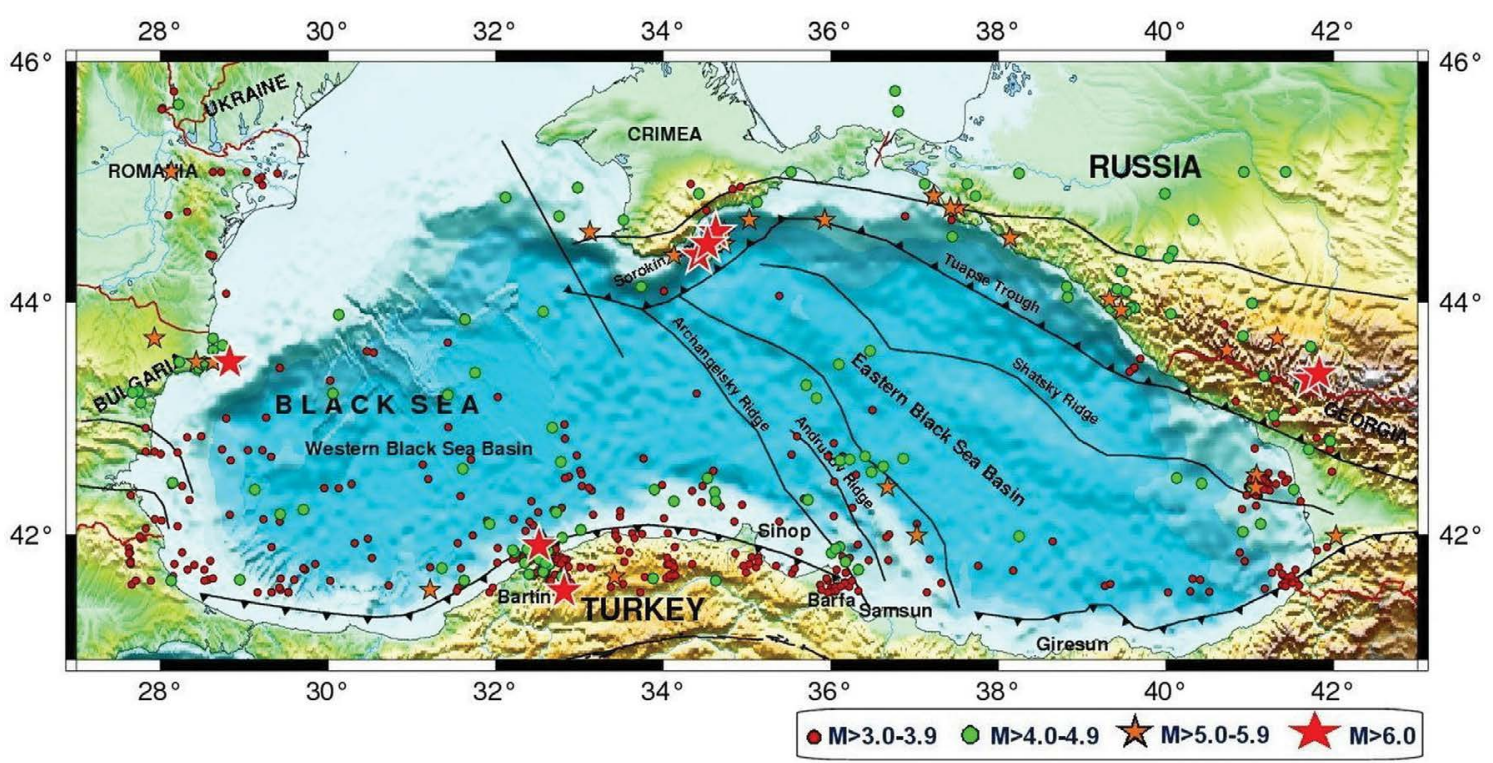

Figure 7: Recent seismic activity of the Black Sea region (red stars show $M \geq 6.0$; orange stars show $M \geq 5.0$; green circles show $M \geq 4.0$ and red circles show $M \geq 3.0$ earthquakes in the period of 1900-2015).

broad-band velocity waveforms for CMT solutions. Usually we calculated moment tensors with Moment Tensor Inversion Techniques [31,32]. We used the earthquakes recorded by at least 4 digital broad-band seismic stations. The earthquakes between 1968 and 2006 we used global data or published results.

The focal mechanisms indicate primarily N-S compression with some E-W component. The mechanisms are consistent with plate motions, where westward motion of the Anatolian Plate and N-S deformation of the Caucasus take up most of the motion of the Arabian Plate. Only small motions (about $1 \mathrm{~mm}$ per year) are transmitted through the Pontides, and the Black Sea is being compressed in an $\mathrm{N}-\mathrm{S}$ direction.
The fault plane solutions of the earthquakes occurred in the Black Sea especially, in recent 6 years, generally have oblique strike-slip faulting in northeastern part (Bulgaria-Romania borderline offshore waters). After 2008 a series of important earthquakes occurred especially in the southern coasts of the Black Sea and offshore Georgia.

In the southern Black Sea and in the middle part, especially offshore of Bartın, around Kastamonu, offshore of Samsun, the reverse faulting component dominated solutions expressing compressional tectonic regime. The strikes of earthquakes generally lie parallel to the basin. This fault geometry shows that a compressional stress is effective in the region. 


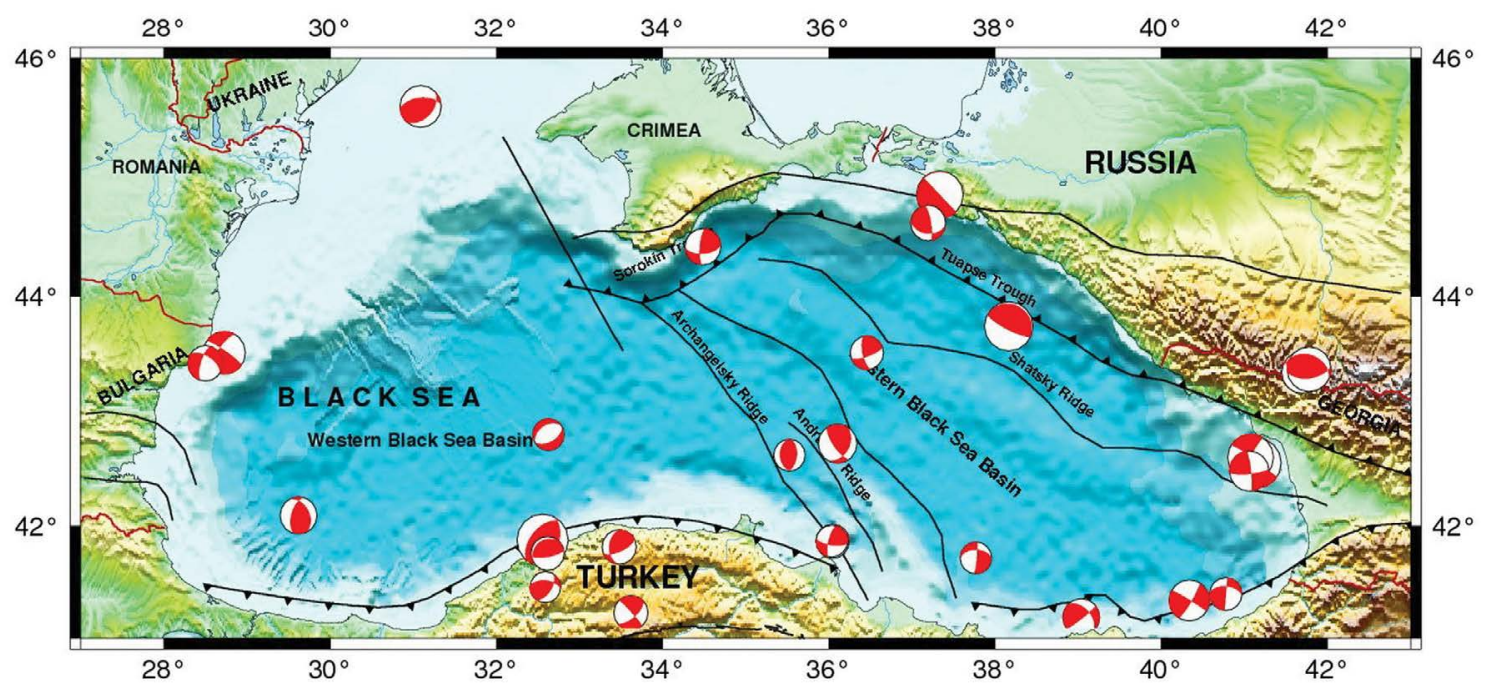

Figure 8: Fault mechanisms in the region (time period: 1968-2015).

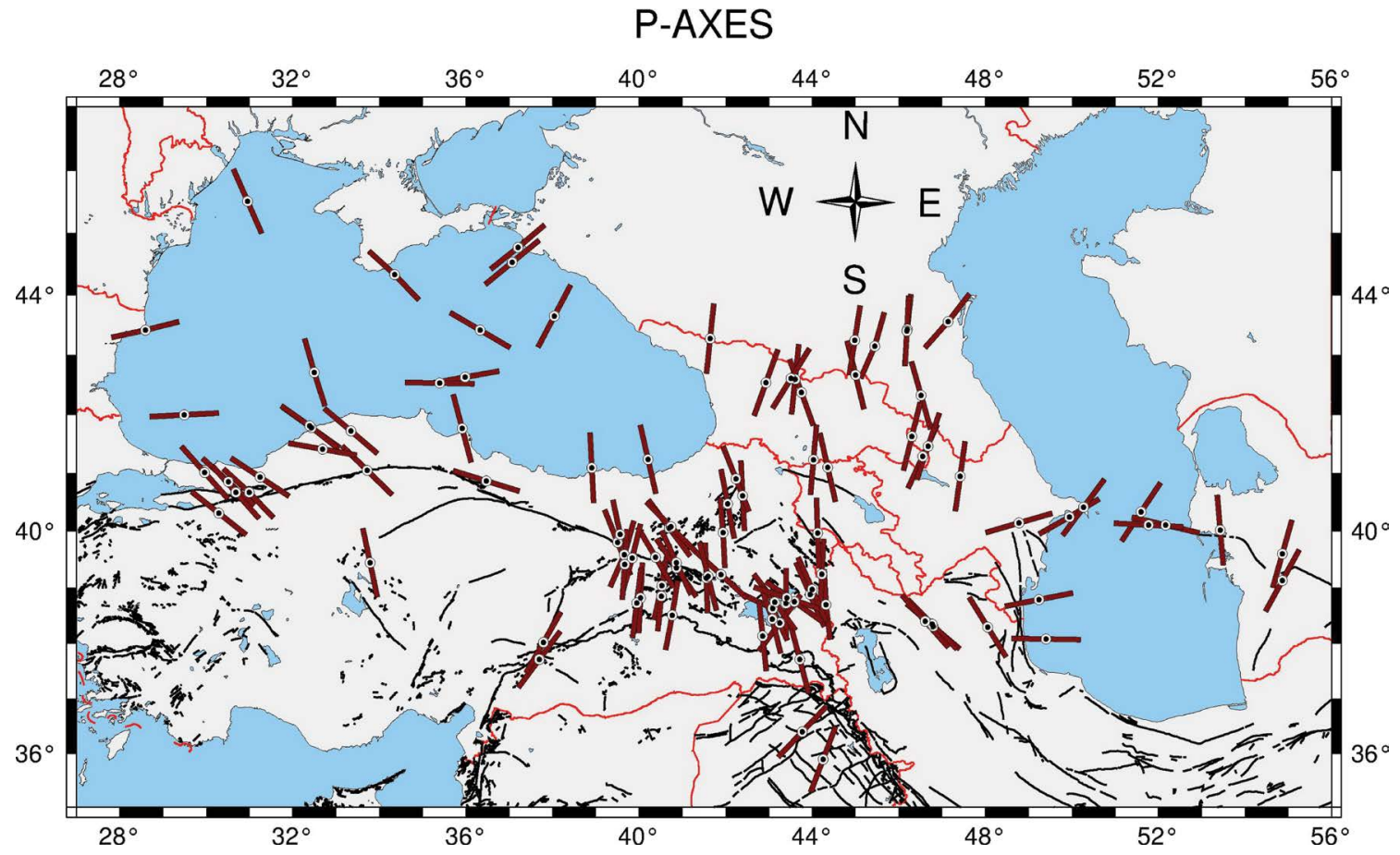

Figure 9: Stress analysis of the region $\mathrm{P}_{\max }$ compressional axes.

The earthquakes in central part of the Black Sea located on faults associated with the ridges.

These earthquakes show that the region is not a seismic and produces earthquakes from time to time, though not very frequently. Offshore of Bafra, earthquake activity started in July 2014 and continued until September 2014 at times causing anxiety in the region.

\section{Conclusions}

The important earthquakes in the region $(\mathrm{Mw}>6.0)$ generally occurred in southeastern Crimea, the Georgia mainland, offshore of Bulgaria, offshore of Bartin (coast of the Black Sea). Since 2005 no other important earthquakes have occurred apart from those. The depths of the earthquakes were generally between 10 and $35 \mathrm{~km}$. Largest earthquakes occurred at the boundaries of Black Sea. The mechanism of the large events at the margins indicates and oblique deformation of the region combined with North-South compression and East-West shear.

Stress pattern based on focal mechanism solutions of the earthquakes in the region show that largest compressional axis $\left(\mathrm{P}_{\max }\right)$ is oriented in NNW-SSE direction. In the eastern part of Black Sea, especially in offshore Georgia, the largest compression axis $\left(\mathrm{P}_{\max }\right)$ is found to be NNE-SSW (Figure 9).

With improved instrumentation many small events have been detected at the shelf margins of the Black Sea. 
It is most likely that this events are located on the faults formed during the opening of the Black Sea.

The deep basin of the Black sea is relatively aseismic. The earthquakes in the central part of the Black Sea are associated with the ridges oriented in SE-NW directions.

\section{Acknowledgments}

This study was supported by the Department of Science Fellowship and Grant programs (2014-2219) of TUBITAK (The Scientific and Technological Research Council of Turkey), Boğaziçi University Research Fund Grant Number 12280 and by Massachusetts Institute of Technology (MIT) The Earth Resources Laboratory (ERL). I express my thanks and appreciation to Prof. M. Nafi Toksöz for his encouragement and assistance.

\section{References}

1. Marc Sosson, Nuretdin Kaymakci, Randell Stephenson, Françoise Bergerat, Vitaly Starostenko (2010) Sedimentary Basin Tectonics from the Black Sea and Caucasus to the Arabian Platform: introduction. Geological Society, London, Special Publications 340: 1-10.

2. Randell Stephenson, Wouter P Schellart (2010) The Black Sea back-arc basin: insights to its origin from geodynamic models of modern analogues. Geological Society, London, Special Publications 340: 11-21.

3. Ara Avagyan, Marc Sosson, Arkadi Karakhanian, Hervé Philip, Samira Rebai, et al. (2010) Recent tectonic stress evolution in the Lesser Caucasus and adjacent regions. Geological Society, London, Special Publications 340: 393-408.

4. Allmendinger R, R Reilinger, J Loveless (2007) Strain and rotation rate from GPS in Tibet, Anatolia and the Altiplano. TECTONICS 26: 1-18.

5. S McClusky, S Balassanian, A Barka, C Demir, S Ergintav, et al. (2000) Global Positioning System constraints on plate kinematics and dynamics in the eastern Mediterranean and Caucasus. Journal of Geophysical Research 105: 56955719.

6. Reilinger R, S McClusky (2011) Nubia-Arabia-Eurasia plate motions and the dynamics of Mediterranean and Middle East tectonics. Geophysical Journal International 186: 971979.

7. Anatoly M Nikishina, Aral I Okayb, Okan Tüysüzb, Ali Demirerc, Nikolay Amelin, et al. (2015) The Black Sea basins structure and history: New model based on new deep penetration regional seismic data. Part 1: Basins structure and fill. Marine and Petroleum Geology 59: 638-655.

8. T Yegorova, T Yanovskaya, V Gobarenko, E Baranova (2010) The crustal structure of the Black Sea from the reinterpretation of deep seismic sounding data acquired in the 1960s. Geological Society 340: 43-56.

9. Rangin C, AG Bader, G Pascal, B Ecevitoğlu, N Görür (2002) Deep structure of the Mid Black Sea High (offshore Turkey) imaged by multi-channel seismic survey (BLACKSIS cruise). Marine Geology 182: 265-278.

10. Anatoly M Nikishina, Aral Okayb, Okan Tüysüzb, Ali Demirerc, Mario Wannierd, et al. (2015) The Black Sea basins structure and history: New model based on new deep penetration regional seismic data. Part 2: Tectonic history and paleogeography. Marine and Petroleum Geology 59: 656-670.

11. Tüysüz O, Yilmaz IÖ, Svabenick L, Kirici S (2012) The Unaz formation: A Key unit in the Western Black Sea Region, N Turkey. Turk J Earth Sci 21: 1009-1028.

12. Munteanu I, Matenco L, Dinu C, Cloetingh S (2011) Kinematics of back-arc inversion of the Western Black Sea Basin. Tectonics 30: 21.

13. Dinu C, Wong HK, Tambrea D, Matenco L (2005) Stratigraphic and structural characteristics of the Romanian Black Sea shelf. Tectonophysics 410: 417-435.

14. Finetti I, G Bricchi, A Del Ben, M Pipan, Z Xuan (1988) Geophysical study of the Black Sea Area. Bollettino di Geofisica Teorica e Applicata 30: 197-324.

15. Meisner LB, AS Gorshkoz, DA Tugolesov (1995) Neogene-quaternary Sedimantation in the Black Sea Basin. In: A Erler, T Ercan, E Bingol, Geology of the Black Sea Basin. S Örçen General Directorate of Min Res and Explor, Ankara, 131-136.

16. Okay Al, O Sahinturk (1997) Geology of the Eastern Pontides. In: AG Robinson, American Association of Petroleum Geologists (AAPG), Regional and Petroleum Geology of the Black Sea and Surrounding Region. AAPG Memoir 68: 291-311.

17. Neprochnov YP, Ross DA (1978) Black Sea geophysical framework. The Deep Sea Drilling Project 1043-1055.

18. Barka A, Reilinger R (1997) Active Tectonics of Eastern Mediterranean region: deduced from GPS, neotectonic and seismicity data. Annali Di Geofisica 3: 587-610.

19. Bozkurt E, Winchester JA, Piper JDA (2000) Tectonics and Magmatism in Turkey and the Surrounding Area. Geological Society 81

20. Jackson J, McKenzie D (1984) Active tectonics of the Alpine-Himalayan Belt between western Turkey and Pakistan. Geophysical Journal of the Royal Astronomical Society 77: 185-264.

21. Alptekin Ö, JL Nabelek, NM Toksöz (1986) Source mechanism of the Bartın earthquake of September 3, 1968 in Northwestern Turkey: evidence for active thrust faulting at the Southern Black Sea margin. Tectonophysics 122: 7388.

22. Kalafat D, Z Öğütçü, M Yilmazzer, M Suvarıklı, Y Güneş, et al. (2005) The first defragments in Turkey are connected Labeled subnets: Blue Net, Orange Net, White Net Projects, Active Research Group, $9^{\text {th }}$ Meeting ATAG9 Abstract Book, Cumhuriyet University, September, 34-36.

23. Y Bayrak, TS Irmak, B Doğan, H Çınar, Ş Yılmaz, et al. (2013) A Preliminary Results of Fault Plane Solutions of the Recent Earthquakes in and Around Eastern Black Sea Region. $7^{\text {th }}$ Congress of Balkan Geophysical Society.

24. Kalafat D (2016) Statistical Evaluation of Turkey Earthquake Data (1900-2015): A Case study. Eastern Anatolian Journal of Science 2: 14-36.

25. Wiemer S (2001) A software package to analyze seismicity: ZMAP. Seismol Res Lett 72: 373-382.

26. Wiemer S, Schorlemmer D (2007) ALM: An Asperity-based Likelihood Model for California. Seismol Res Lett 78: 134140. 
27. Woessner J, S Wiemer (2005) Assessing thequality of earthquake catalogues: estimating the magnitude of completeness and its uncertainty. Bull Seism Soc Am 95: 684-698.

28. O Alptekin, JN Nabalek, ve MN Toksöz (1985) 3 Eylül 1968 Bartın Depreminin Kaynak Mekanizması ve Karadeniz'in Aktif Tektoniği Hakkında Düşünceler. 60: 5-38.

29. HRV (1977-2013) Harvard Centroid - Moment Tensor Project CMT, Harvard University, MA, USA.
30. Kalafat D (1998) Anadolu'nun Tektonik Yapılarının Deprem Mekanizmaları Açısından irdelenmesi. Deprem Araştırma Bülteni 77: 1-217.

31. Dreger D (2002) Manual of the Time- Domain Moment Tensor Inverse Code (TDMT_INVC) Version 1.1. Berkeley Seismology Laboratory 18.

32. Sokos E, Zahradník J (2013) Evaluating Centroid Moment Tensor Uncertainty in the New Version of ISOLA Software. Seismological Research Letters 84: 656-665. 